DOI: $10.21802 / \operatorname{artm} .2021 .3 .19 .36$

UDC 616-08+616.14+616.61

\title{
TREATMENT OF AORTA MESENTERIC COMPRESSION: CURRENT PROBLEMS AND PROSPECTS
}

\author{
I.R. Nesterenko
}

\begin{abstract}
Ivano-Frankivsk National Medical University, Department of General Surgery, Vascular surgeon, Ivano-Frankivsk Regional Clinical Hospital, Ivano-Frankivsk, Ukraine, ORCID ID: 0000-0002-8358-291X, e-mail:nesterenko-irenka@ukr.net
\end{abstract}

\begin{abstract}
Left renal vein compression between the aorta and the superior mesenteric artery at an acute angle of the origin of the latter ("the nutcracker syndrome") often leads to phlebohypertension in the left renal vein causing a combination of structural and functional changes in the kidneys and pelvic organs, different clinical manifestations such as left-sided varicocele, hematuria, pelvic venous congestion syndrome, the development of renal failure.

The objective of the research: to determine indications for surgical and conservative treatment of aorta mesenteric compression.

Materials and methods. The study included 210 patients (142 men and 68 women) with suspected "nutcracker syndrome" who were referred to vascular surgeons for a consultation by urologists and gynecologists during the period from 1999 to 2020, mainly from the western regions of Ukraine (about 11 million population). The age of the patients ranged from 12 to 52 . All patients were interviewed for specific complaints: pain in the left lumbar region and left half of abdomen, inability to eat large amounts of food, hematuria, proteinuria, hemospermia, erectile dysfunction, left sided varicocele in men, and left sided pudendal varicosity and dysmenorrhea in women. All referred patients with suspected "nutcracker syndrome" underwent color Doppler ultrasound to determine the presence of pathological reflux in the left renal and gonadal veins by measuring peak systolic velocities in order to confirm or exclude that pathology. The patients with confirmed left renal vein stenosis underwent CT angiography.

Results. According to color Doppler ultrasound, different degree of aorta mesenteric compression was confirmed in $138(65.7 \%)$ patients (83 men and 55 women), critical left renal vein stenosis was observed in 35 of them. Two patients were diagnosed with the retroaortic left renal vein ("posterior nutcracker").

According to observations, clinical manifestations of AMC syndrome severe forms occurred in case of an increase in the diameter of the distal part of the LRV compared to its proximal segment by 3-6 times as well as in case of an increase in peak systolic velocity in the stenosed proximal segment by 6-14 times (by 8.7 times on average) compared to the left renal vein distal segment.

Conclusions. Color Doppler ultrasound with determination of peak systolic velocities and diameters of the left renal and gonadal veins, pathological reflux in them must be the obligatory diagnostic stage in the patients with suspected AMC. The choice of treatment approach should be made taking into account clinical and laboratory indices, as well as the assessment of AMC severity according to instrumental data (ultrasound, CT angiography, MRA, etc.). The severity of pathomorphological changes in the pelvic organs and their consequences proves the need to eliminate phlebohypertension in the left renal and gonadal veins. LRV transposition proves its effectiveness in the remote postoperative period.
\end{abstract}

Keywords: "the nutcracker syndrome", phlebohypertension, aorta mesenteric clamp.

Introduction. Left renal vein compression between the aorta and the superior mesenteric artery at an acute angle of the origin of the latter ("the nutcracker syndrome") often leads to phlebohypertension in the left renal vein (LRV) causing a combination of structural and functional changes in the kidneys and pelvic organs, different clinical manifestations such as left-sided varicocele, hematuria, pelvic venous congestion syndrome, the development of renal failure. Although the connection of left-sided varicocele with the aorta mesenteric clamp (AMC) was indicated by Lopatkin MA in his monograph "Stenosis of the left renal vein" in the 70-ies of last century [6], and in 2016 Kapto AA in the new classification of varicocele identified the syndrome of "the nutcracker" as the cause of 3 types of varicocele [1], this pathology is very rarely diagnosed up to the present day. According to the Mayo Clinic, one in five women consults a doctor complaining of pain syndrome associated with varicose veins of the pelvis, however, the correct diagnosis is made in only $2 \%$ of cases, up to $40 \%$ of unreasonable hysterectomies are associated with undiagnosed pelvic venous congestion syndrome (Annual medical bulletin Mayo Clinic, 1999). According to Coolsaet, the cause of pelvic venous congestion syndrome is "the nutcracker syndrome" in $74 \%$ of cases, May-Thurner syndrome in $17 \%$ of cases, and a combination of these two causes in $9 \%$ of cases [8]. The interest in "the nutcracker syndrome" has grown significantly over the past two decades, as evidenced by the growing number of citations in PubMed (Fig.1), however, there are currently no multicenter randomized researches and clear guidelines for the diagnosis and treatment of this pathology. 


\section{2 results}

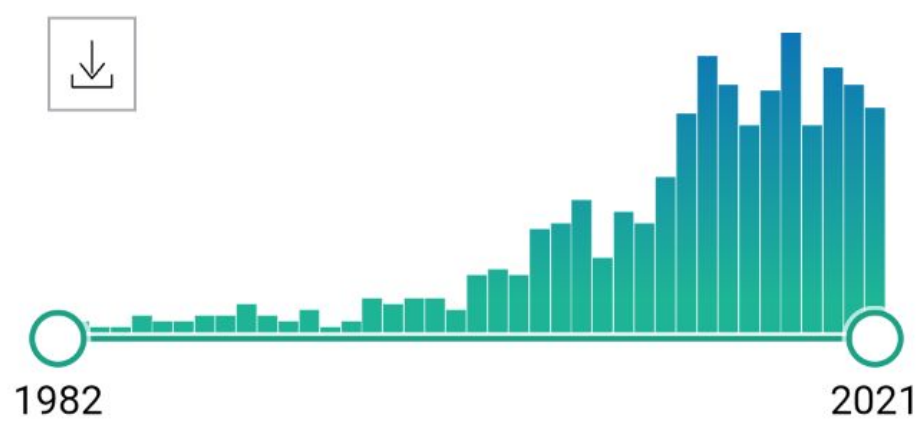

\section{Nutcracker syndrome.}

Fig. 1. The frequency of "the nutcracker syndrome" citations according to PubMed.

The objective of the research: to determine indications for surgical and conservative treatment of AMC.

Materials and methods. The study included 210 patients (142 men and 68 women) with suspected "nutcracker syndrome" who were referred to vascular surgeons for a consultation by urologists and gynecologists during the period from 1999 to 2020, mainly from the western regions of Ukraine (about 11 million population). The age of the patients ranged from 12 to 52 . All patients were interviewed for specific complaints: pain in

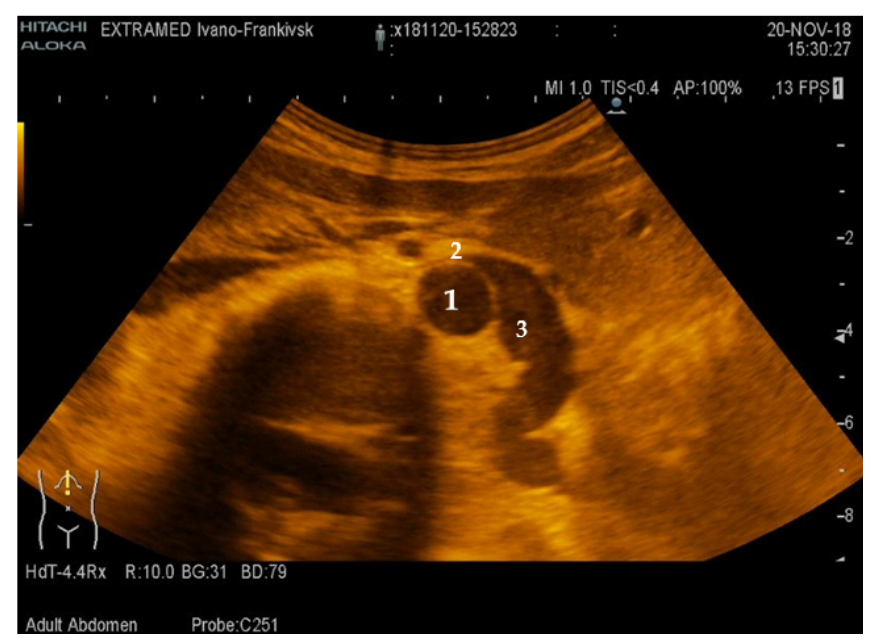

Fig. 2. Ultrasound pattern of "the nutcracker syndrome" in the B-mode (1 - aorta, 2 - stenosed part of LRV, 3 - dilated part of LRV). the left lumbar region and left half of abdomen, inability to eat large amounts of food, hematuria, proteinuria, hemospermia, erectile dysfunction, left sided varicocele in men, and left sided pudendal varicosity and dysmenorrhea in women. All referred patients with suspected "nutcracker syndrome" underwent color Doppler ultrasound to determine the presence of pathological reflux in the left renal and gonadal veins by measuring peak systolic velocities in order to confirm or exclude that pathology. The patients with confirmed left renal vein stenosis underwent CT angiography.

Results of the research. According to color Doppler ultrasound, different degree of aorta mesenteric clamp (AMC) was confirmed in $138(65.7 \%)$ patients (83 men and 55 women), critical LRV stenosis was observed in 35 of them. Two patients were diagnosed with the retroaortic LRV ("posterior nutcracker"). Particular attention was paid to the difference in the LRV diameters in the distal part and in the aorto-mesenteric segment, as well as to the difference in the peak blood flow velocities in these areas.

The ultrasound pattern of "the nutcracker syndrome" was characterized by a sharp narrowing of the LRV diameter in the aorto-mesenteric segment and prestenotic expansion in the distal part, which correlated with a corresponding increase in peak systolic velocity in the stenosed part of the LRV.

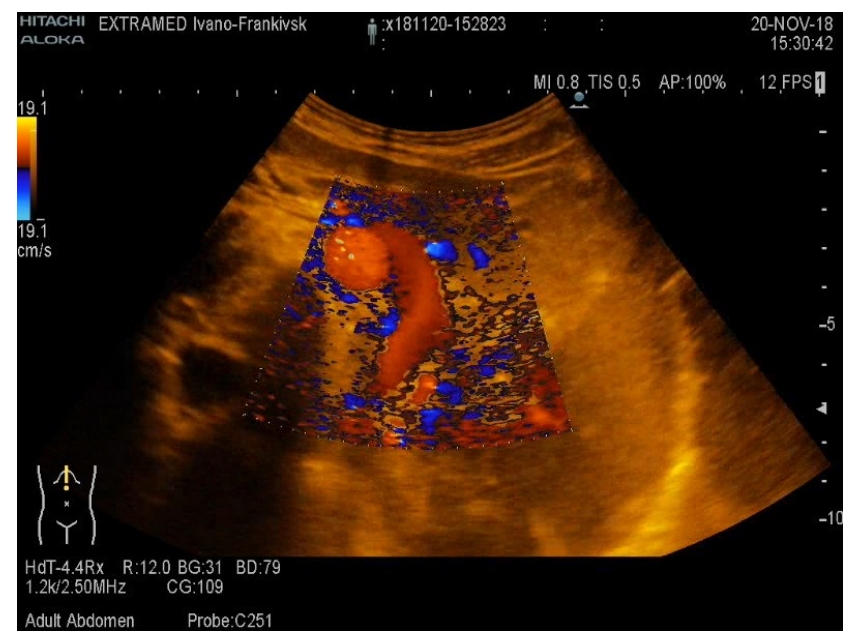

Fig. 3. Ultrasound pattern of "the nutcracker syndrome" (color Doppler mode). 


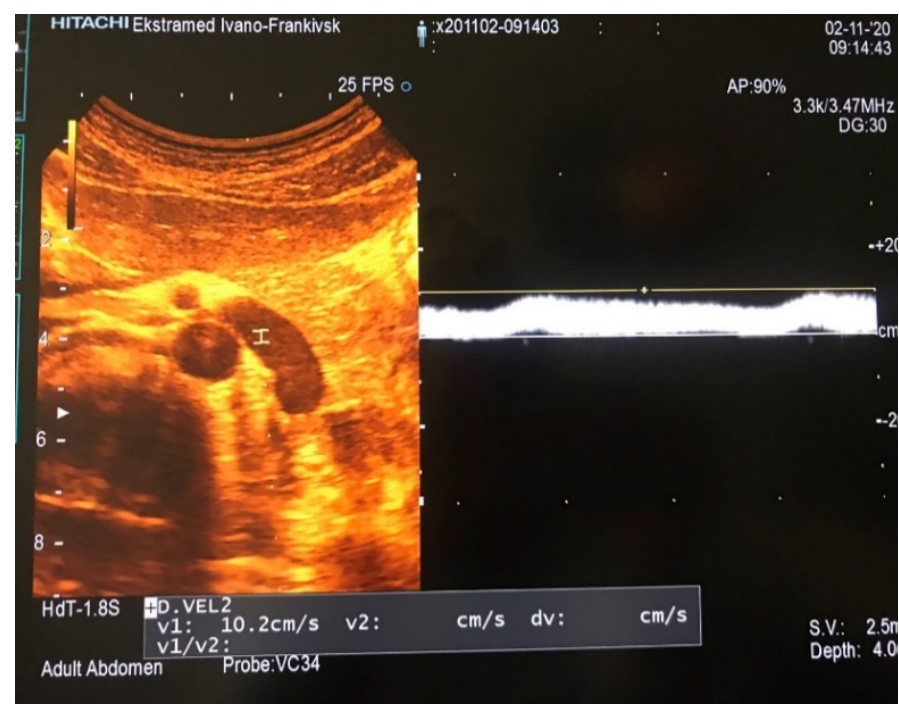

Fig. 4. Measurement of peak systolic velocity in the dilated LRV segment.

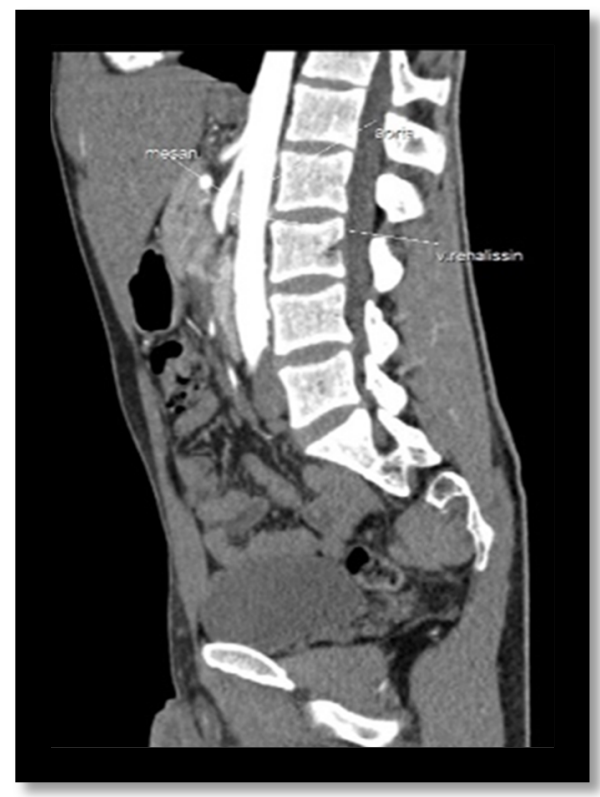

Fig. 6. CT angiography of a patient with "the nutcracker syndrome" (sagittal plane).

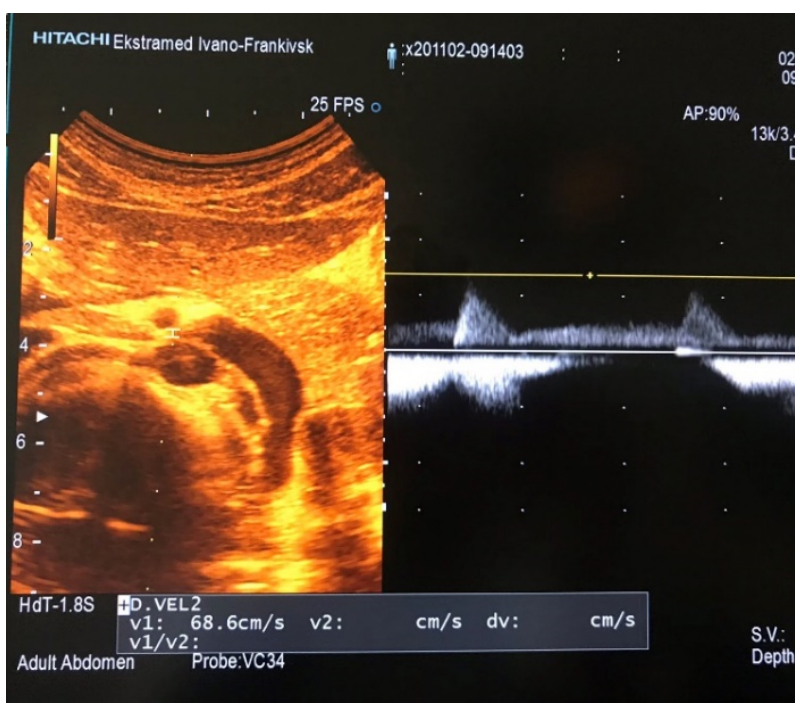

Fig. 5. Measurement of peak systolic velocity in the stenosed LRV segment.

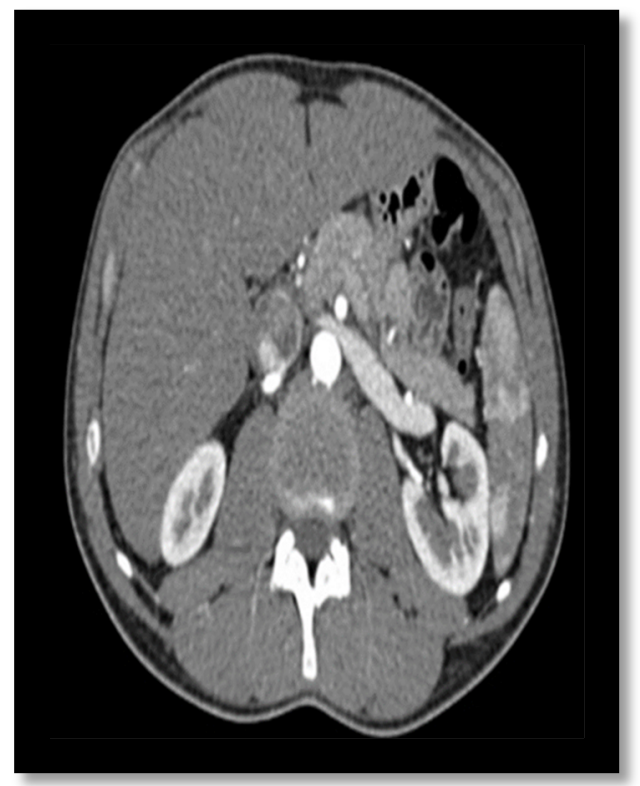

Fig. 7. CT angiography of a patient with "the nutcracker syndrome" (transversal projection).

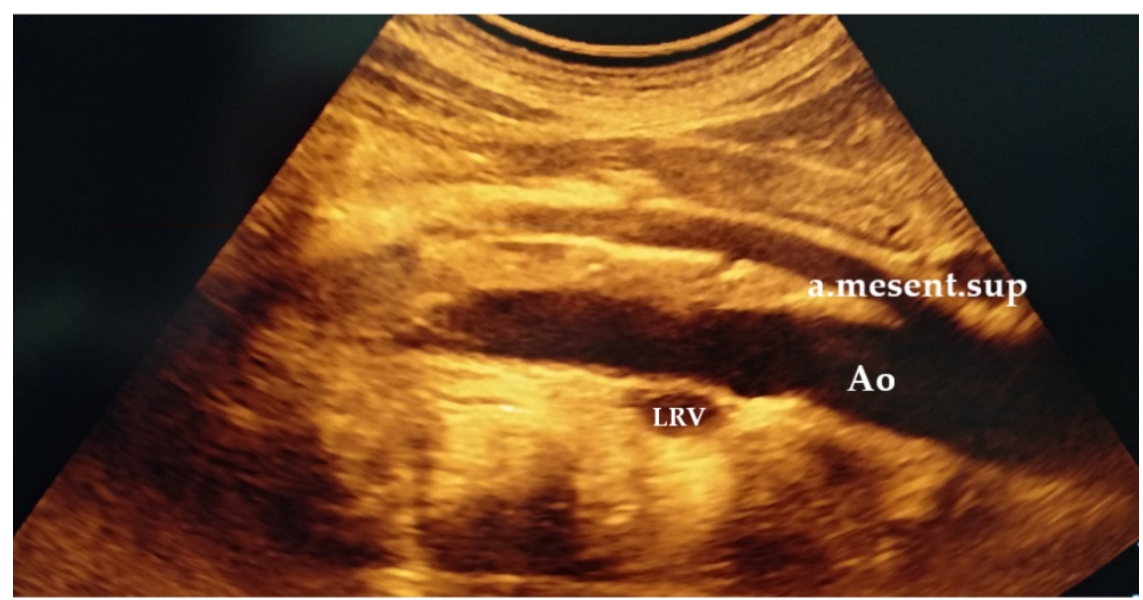

Fig. 8. Retroaortic position of the LRV ("the posterior nutcracker"). 


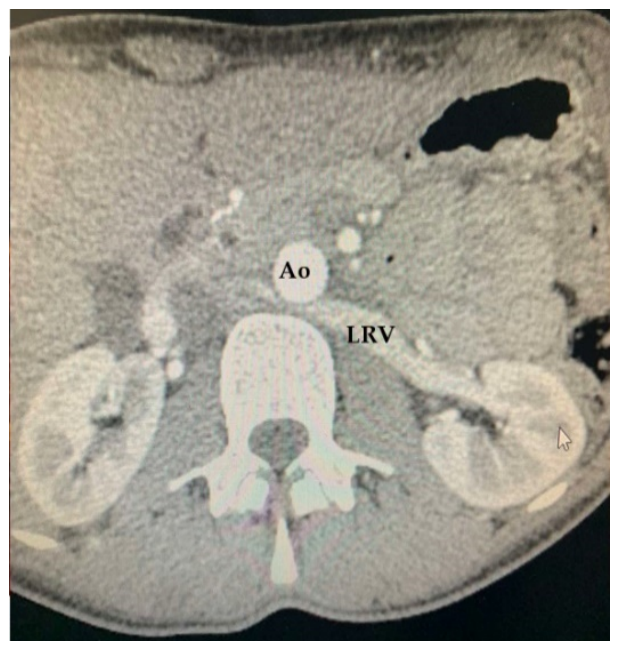

\section{roaortic LRV}

Fig. 9. CT-angiography of a patient with ret-

According to observations, clinical manifestations of AMC syndrome severe forms occurred in case of an increase in the diameter of the distal (prestenotic) part of the LRV compared to its proximal (aorto-mesenteric) segment by 3-6 times as well as in case of an increase in peak systolic velocity in the stenosed proximal (aortomesenteric) segment by 6-14 times (by 8.7 times on average) compared to the LRV distal segment. Indices of the ratio of the diameters of LRV distal and proximal segments $\geq 3$ and the ratio of peak systolic velocities in the proximal and distal segments $\geq 6$ were evaluated as critical LRV stenosis [2], [3].

Clinical manifestations of aorta mesenteric clamp were caused by the development of phlebohypertension in the system of the left renal vein and the left gonadal vein directly flowing into the left renal vein.
The main clinical manifestations of aorta mesenteric clamp were:

- $\quad$ pain in the left half of abdomen and left lumbar region $(87.7 \%)$;

- macrohematuria or microhematuria (19.2\%);

- $\quad$ proteinuria $(7.2 \%)$;

- $\quad$ anemia (4.8\%);

- $\quad$ left sided varicocele in men (57.8\%);

- left sided pudendal varicosity in women $(12.7 \%)$;

- $\quad$ erectile dysfunction $(33.7 \%)$;

- dysmenorrhea (69\%);

- dyspareunia (11\%).

The patients noted the presence of hemospermia $(3.6 \%)$ and increased pain after eating and during exercise $(12 \%)$ less often, pain irradiation to the inner thigh and in the left lumbar region was characteristic. The vast majority of patients were of asthenic bodybuild with weight deficit (BMI $\leq 21$ in $98 \%$ ). The severity of clinical symptoms clearly correlated with the level of hypertension in the left renal vein and the degree of its compression. Due to non-specific clinical symptoms, patients are often unsuccessfully treated for years by urologists, gynecologists and gastroenterologists and are often considered by doctors as patients with neurasthenic manifestations. Patients with left-sided varicocele deserve special attention, in particular those with the recurrent one. According to Sahalevych AI, more than $74 \%$ of patients with left-sided varicocele have different degrees of aorta mesenteric clamp [7].

Since there are no randomized studies on the management of patients with aorta mesenteric clamp nowadays, the choice of treatment remains an urgent problem. Treatment approach depends on the degree of functional and structural changes in the left kidney and pelvic organs, as well as the severity of clinical manifestations. We have developed a point scale for the evaluation of indications for various treatment methods.

Table 1

\section{POINT SCALE FOR EVALUATION OF "THE NUTCRACKER SYNDROME" SEVERITY ACCORDING} TO CLINICAL SYMPTOMS

\begin{tabular}{|c|c|c|c|}
\hline \multicolumn{1}{|c|}{$\mathbf{4}$ points } & 3 points & $\mathbf{2}$ points & $\mathbf{1}$ point \\
\hline $\begin{array}{c}\text { Macrohematuria duration }> \\
24 \text { months }\end{array}$ & $\begin{array}{c}\text { Macrohematuria duration }<12 \\
\text { months, more than 2 times }\end{array}$ & $\begin{array}{c}\text { Microhematuria } 1-2 \\
\text { times }\end{array}$ & $\begin{array}{c}\text { Hemospermia or } \\
\text { blood during } \\
\text { coitus }\end{array}$ \\
\hline $\begin{array}{c}\text { Left-sided varicocele* in } \\
\text { men, stage III }\end{array}$ & $\begin{array}{c}\text { Left-sided varicocele in men, stage } \\
\text { II }\end{array}$ & $\begin{array}{c}\text { Left-sided varicocele in } \\
\text { men, stage I }\end{array}$ & $\begin{array}{c}\text { Erectile dysfunc- } \\
\text { tion }\end{array}$ \\
\hline $\begin{array}{c}\text { Duodenal obstruction syn- } \\
\text { drome** } \\
\text { (severe form) }\end{array}$ & $\begin{array}{c}\text { Duodenal obstruction syndrome** } \\
\text { (mild severity) }\end{array}$ & $\begin{array}{c}\text { Left-sided pudendal } \\
\text { varicose veins in wom- } \\
\text { en }\end{array}$ & $\begin{array}{c}\text { Arterial hyper- } \\
\text { tension }\end{array}$ \\
\hline $\begin{array}{c}\text { Constant sever left-sided pain } \\
\text { in the lumbar region } \\
\text { in the half of the abdomen } \\
\text { in the pelvic area requir- } \\
\text { ing analgesics }\end{array}$ & $\begin{array}{c}\text { Constant severe left-sided pain } \\
\text { in the lumbar region } \\
\text { in the half of the abdomen } \\
\text { in the pelvic area not requiring } \\
\text { analgesics }\end{array}$ & $\begin{array}{c}\text { Intermittent moderate } \\
\text { left-sided pain } \\
\text { in the lumbar region } \\
\text { in the half of the ab- } \\
\text { domen }\end{array}$ & $\begin{array}{c}\text { Dysmenorrhea } \\
\text { in the pelvic area }\end{array}$ \\
\hline
\end{tabular}


*Classification of varicocele by the WHO:

- Grade I: varicose veins in the scrotum are not visible or palpable, except for their expansion in the Valsalva maneuver;

- Grade II: varicose veins in the scrotum are not visible, but easily palpable;

- Grade III: varicose plexuses protrude through the skin of the scrotum and are easily palpated [4].

**Duodenal obstruction syndrome - inability to eat large amounts of food due to increased abdominal pain.

Table 2

POINT SCALE FOR EVALUATION OF “THE NUTCRACKER SYNDROME" SEVERITY ACCORDING TO LABORATORY FINDINGS (COMPLETE BLOOD COUNT, URINE ANALYSIS, SPERMATOGRAM)

\begin{tabular}{|l|l|l|l|}
$\mathbf{4}$ points & \multicolumn{1}{|c|}{$\mathbf{3}$ points } & \multicolumn{1}{c|}{$\mathbf{2}$ points } & \multicolumn{1}{c|}{$\mathbf{1}$ point } \\
\hline & Macrohematuria & Orthostatic proteinuria & Microhematuria \\
\hline & Significant changes in the spermogram & Moderate & Minimal \\
\hline & Anemia * severe & Moderate & Mild \\
\hline
\end{tabular}

*Haemoglobin concentrations for the diagnosis of anaemia and assessment of severity. Vitamin and Mineral Nutrition Information System (VMNIS). World Health Organization (2011).

Table 3

POINT SCALE FOR EVALUATION OF “THE NUTCRACKER SYNDROME" SEVERITY ACCORDING TO INSTRUMENTAL DATA (ULTRASOUND, CT ANGIOGRAPHY, MRA, ETC)

\begin{tabular}{|c|c|c|c|}
\hline 4 points & 3 points & 2 points & 1 point \\
\hline $\begin{array}{l}\text { The ratio of PSV in proximal and distal } \\
\text { segments of } L R V \geq 5\end{array}$ & $\geq 4$ & $\mathrm{LRV} \geq 3$ & \\
\hline $\begin{array}{l}\text { The ratio of LRV diameters in proximal and } \\
\text { distal segments } \geq 5\end{array}$ & $\geq 4$ & $\geq 3$ & \\
\hline $\begin{array}{l}\text { Increase in the size of the left kidney } \geq 2 \\
\mathrm{~cm}\end{array}$ & $\geq 1.5 \mathrm{~cm}$ & $\geq 1 \mathrm{~cm}$ & $\geq 0.5 \mathrm{~cm}$ \\
\hline The angle of SMA origin from aorta $\leq 9^{\circ}$ & $\begin{array}{l}\text { The angle of SMA } \\
\text { origin from aorta } \leq 19^{\circ}\end{array}$ & $\begin{array}{l}\text { The angle of SMA } \\
\text { origin from aorta } \leq 29^{\circ}\end{array}$ & $\begin{array}{l}\text { The angle of } \\
\text { SMA origin from } \\
\text { aorta } \leq 39^{\circ}\end{array}$ \\
\hline LRV saccular aneurysm & $\begin{array}{l}\text { Saccular aneurysm or } \\
\text { gonadal vein throm- } \\
\text { bosis }\end{array}$ & $\begin{array}{l}\text { Pelvic varicose veins } \\
\text { mostly on the left }\end{array}$ & \\
\hline
\end{tabular}

Table 4

\section{RECOMMENDATIONS}

\begin{tabular}{|l|l|}
\hline $0-9$ & Predominantly conservative treatment \\
\hline $10-19$ & Predominantly surgical treatment \\
\hline$\geq 20$ & Only surgical treatment \\
\hline
\end{tabular}

Conservative treatment involved the use of venoactive drugs, diosmin with hesperidin in particular. Patients were recommended to undergo ultrasound control every 6 months and laboratory monitoring including urine analysis, Nechiporenko test, complete blood count. Surgical correction of phlebohypertension in the left renal vein system was performed by reimplantation (transposition) of the left renal vein with its shifting below the site of compression, which proved its effectiveness in the remote postoperative period [4].

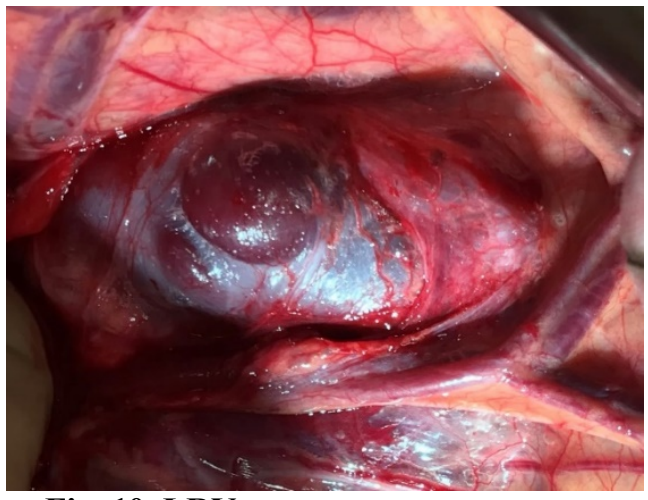

Fig. 10. LRV aneurysm. 


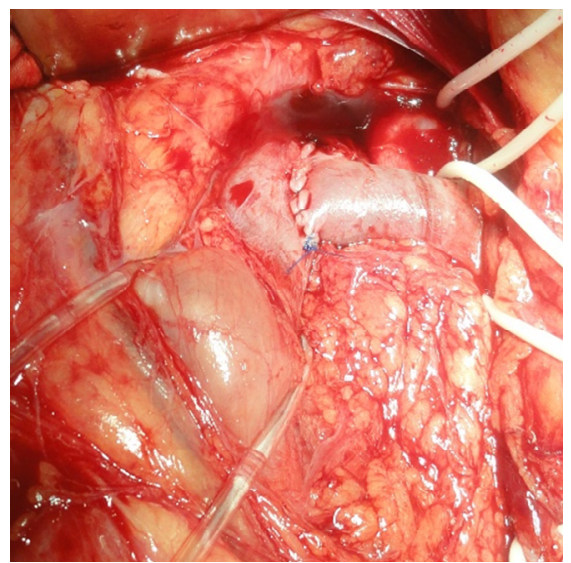

Fig. 11. Reimplanted LRV.

Discussion. Left renal vein transposition was first performed in 1982 by Stewart and involved detachment of the left renal vein from the inferior vena cava, suturing of the inferior vena cava defect and reanastomosis below the superior mesenteric artery. The advantages of the method included a short period of renal ischemia; the disadvantages comprised the risk of the left renal vein thrombosis, bleeding, gastroparesis [10]. Despite attempts to diversify the surgical correction of this pathology (superior mesenteric artery transposition, laparoscopic extravascular stenting, endovascular stenting, etc.), the best results in the remote postoperative period were demonstrated by the left renal vein transposition [10]. The activity concerning "the nutcracker syndrome" detection and diagnosis has increased slightly after the first published results of its treatment, however, the non-specificity of symptoms, lack of diagnostic algorithms and low awareness of doctors still refer "the nutcracker syndrome" to rarely diagnosed pathologies. According to the Mayo Clinic, only 112 cases of surgical treatment of "the nutcracker syndrome" have been described in the literature so far. The countries with the highest incidence of "the nutcracker syndrome" include the countries of North America and Western Europe. However, such distribution of epidemiological data is probably caused by higher awareness and vigilance of doctors about this diagnosis.

The situation with the detection, diagnosis and treatment of this disease remains problematic in Ukraine. In 2018 a report on endovascular treatment of "the nutcracker syndrome" appeared in press for the first time. Three patients underwent successful stenting of the left renal vein in Zaporizhzhia (professor Nykonenko AO).

Since 1999, 33 patients with "the nutcracker syndrome" have been operated on at the Lviv Regional Clinical Hospital with the participation of professor Kobza II. Thus, the recovery rate of patients with this pathology remains extremely low, and the manifestations of "the nutcracker syndrome", varicocele in particular, are a significant problem due to the high recurrence rate after Ivanissevich surgery ( 8.6 to $25 \%$ ) since this intervention does not eliminate the main pathogenetic mechanism of varicocele occurrence in case of this disease, namely phlebohypertension in the left renal vein.

\section{Conclusions:}

1. Color Doppler ultrasound with determination of peak systolic velocities and diameters of the left renal and gonadal veins, pathological reflux in them must be the obligatory diagnostic stage in the patients with suspected AMC.

2. The choice of treatment approach should be made taking into account clinical and laboratory indices, as well as the assessment of AMC severity according to instrumental data (ultrasound, CT angiography, MRA, etc.).

3. The severity of pathomorphological changes in the pelvic organs and their consequences proves the need to eliminate phlebohypertension in the left renal and gonadal veins.

4. LRV transposition proves its effectiveness in the remote postoperative period.

\section{References:}

1. Kapto AA. Klinicheskiye aspekty sosudistoy anatomii u patsiyentov s varikotsele (lektsiya). Eksperimentalnaya i klinicheskaya urologiya. 2006; 2:70-79.

2. Kobza II, Nesterenko IR, Nesterenko VL. Diahnostychno-likuvalna taktyka pry aortomezenterialnomu pintseti. Halytskyi likarskyi visnyk. 2018; 3:58-62.

3. Kobza II, Nesterenko IR, Nesterenko VL. Ultrasound characteristics of the nutcracker syndrome. Archive of Clinical Medicine. 2018; 2:2-16. DOI: 10.21802/acm.2018.2.9

4. Kobza II, Nesterenko IR, Nesterenko VL. Optymizatsiya khirurhichnoii taktyky u patsiientiv z "syndromom Luskunchyka”. Klinichna anatomiia ta operatyvna khirurhiia. 2019; 18(2):70-77.

5. Kobza II, Nesterenko IR, Nesterenko VL, et.al. Remote results of the nutcracker syndrome surgical treatment. Hospital Surgery. 2019; 4:89-94. DOI: https://doi.org/10.11603/2414-4533.2019.4.10717

6. Lopatkin NA, Morozov AK, Zhitnikova LN. Stenoz pochechnoy veny. Moscow. 1984; P.146.

7. Sahalevych AI. Patohenetychne obhruntuvannia metodiv khirurhichnoho likuvannia livostoronnioho varykotsele. Thesis. 2002.

8. Coolsaet BL. Ureteric pathology in relation to right and left gonadal veins. Urology. 1978; 12(1):40-49.

9. Kurklinsky AK, Rooke TW. Nutcracker phenomenon and nutcracker syndrome. Mayo Clin. Proc. 2010; 85:552-559.

10. Velasquez CA, Saeyeldin A, Zafar MA, Brownstein AJ, Erben Y. A systematic review on management of nutcracker syndrome. J. Vasc. Surg. Venous Lymphat. Disord. 2018; 6:271-278.

\section{УДК 616-08+616.14+616.61 ЛЕЧЕНИЕ СИНДРОМА АОРТО-МЕЗЕНТЕРИАЛЬНОЙ КОМПРЕСИИ: ТЕКУЩИЕ ПРОБЛЕМЫ И ПЕРСПЕКТИВЫ}

\section{И.Р. Нестеренко}

\begin{abstract}
Ивано-Франковский нацчиональный медицинский университет, кафедра общей хирургии, КНП «Обласная клиническая больница», 2. Ивано-Франковск, Украина,
\end{abstract}

ORCID ID: 0000-0002-8358-291X, e-mail: nesterenko-irenka@ukr.net 
Резюме. Компрессия левой почечной вены между аортой и верхней брыжеечной артерии при остром угле отхождения последней часто приводит к развитию флебогипертензии в системе левой почечной вены (ЛПВ), которая запускает каскад структурных и функциональных изменений почек и органов малого таза с многообразием клинических проявлений - от левостороннего варикоцеле, гематурии, синдрома тазовой венозной конгестии вплоть до развития почечной недостаточности.

Цель. Сформировать показания к хирургическому и консервативному лечению синдрома аортомезентериальной компресии (АМК).

Материалы и методы. В исследование вошло 210 пациентов (142 мужчин и 68 женщин) с подозрением на синдром «щелкунчика» с 1999 по 2020 гг. Bce пациенты были опрошены на предмет специфических жалоб. Всем пациентам проводилась ультразвуковая цветная допплерография с определением наличия патологических рефлюксов в левой почечной и гонадной венах с измерением пиковых систолических скоростей. Пациентам с подтвержденными стенозом ЛПВ проводилась КТ - ангиография.

Результаты. В 138 (65,7\%) пациентов (83 мужчин и 55 женщин) по данным ультразвуковой цветной допплерографии подтверждено разную степень АМК, в 35-ти из них - критический стеноз ЛПВ. Клинические проявления синдрома АМК продиктованы развитием флебогипертензии в системе левой почечной вены.

Выводы. Обязательным диагностическим этапом у пациентов с подозрением на синдром АМК должна быть ультразвуковая цветная допплерография. Выбор метода лечения должен проводиться с учетом клинических и лабораторных показателей, а также за инструментальными данными (УЗИ, КТА, MPA и др.). Выраженность патоморфологических изменений органов малого таза и их последствия доказывает необходимость ликвидации флебогипертензии в системе левой почечной и гонадной вен. Транспозиция ЛНВ доказывает свою эффективность в отдаленном послеоперационном периоде.

Ключевые слова: «синдром щелкунчика», флебогипертензия, аорто - мезентериальный пинцет.

\section{УДК 616-08+616.14+616.61 \\ ЛІКУВАННЯ СИНДРОМУ \\ АОРТО-МЕЗЕНТЕРІАЛЬНОЇ КОМПРЕСЇ̈: ПОТОЧНІ ПРОБЛЕМИ ТА ПЕРСПЕКТИВИ}

\section{I.P. Нестеренко}

Івано-Франківський національний медичний університет, кафедра загальної хірургії, КНП «Обласна клінічна лікарня Івано - Франківської обласної ради»,

м. Івано-Франківськ, Україна,

ORCID ID: 0000-0002-8358-291X,

e-mail: nesterenko-irenka@ukr.net

Резюме. Компресія лівої ниркової вени між аортою та верхньою брижовою артерією при гострому куті відходження останньої (синдром «лускунчика») часто призводить до розвитку флебогіпертензії в системі лівої ниркової вени (ЛНВ), яка запускає каскад структурних та функціональних змін нирок та органів малого тазу з різноманіттям клінічних проявів - від лівобічного варикоцеле, гематурії, синдрому тазової венозної конгестії аж до розвитку ниркової недостатності.

Мета. Сформувати покази до хірургічного та консервативного лікування синдрому аортомезентеріальної компресії (АМК).

Матеріали та методи. У дослідження увійшло 210 пацієнтів (142 чоловіків і 68 жінок) з підозрою на синдром «лускунчика» з 1999 по 2020 р. Всі пацієнти були опитані на предмет специфічних скарг. Усім пацієнтам проводилась ультразвукова кольорова допплерографія з визначенням наявності патологічних рефлюксів у лівій нирковій та гонадній венах 3 вимірюванням пікових систолічних швидкостей. Пацієнтам з підтвердженим стенозом ЛНВ проводилась КТ - ангіографія.

Результати. У 138 (65,7 \%) пацієнтів (83 чоловіків та 55 жінок) згідно 3 даними ультразвукової кольорової допплерографії підтверджено різний ступінь аорто-мезентеріальної компресії (АМК), у 35-ти 3 них - критичний стеноз ЛНВ.

Висновки. Обов'язковим діагностичним етапом у пацієнтів 3 підозрою на синдром АМК має бути ультразвукова кольорова допплерографія. Вибір методу лікування повинен проводитись 3 урахуванням клінічних та лабораторних показників, а також оцінки важкості синдрому АМК за інструментальними даними (УЗД, КТА, МРА та ін.). Вираженість патоморфологічних змін органів малого тазу та їх наслідки доводить необхідність ліквідації флебогіпертензії в системі лівої ниркової та гонадної вен. Транспозиція ЛНВ доводить свою ефективність у віддаленому післяопераційному періоді.

Ключові слова: «синдром лускунчика», флебогіпертензія, аорто-мезентеріальна компресія. 